\title{
Optimization of recipe for development of Aonla squash- A Response surface methodology approach
}

\author{
Akanksha Jain $^{1 *}$, Rakesh Gehlot ${ }^{2}$, Saleem Siddiqui ${ }^{3}$ and Mukesh R. Jangra ${ }^{4}$ \\ ${ }^{1,2,3}$ Centre of Food Science and Technology, CCSHAU, Hisar -125004 (Haryana), INDIA \\ ${ }^{4}$ Department of Molecular Biology, Biotechnology and Bioinformatics, College of Basic Sciences, CCSHAU, \\ Hisar -125004 (Haryana), INDIA \\ *Corresponding author. E-mail:akankshajain972@gmail.com
}

Received: October 09, 2015; Revised received: March 30, 2016; Accepted: July 25, 2016

\begin{abstract}
Central Composite Design (CCD) was employed for optimizing the recipe for development of Aonla squash with juice content (25 to $40 \%$ ), acidity (1.00 to $1.10 \%$ ) as independent variables and adjusting $50 \%$ total soluble solids. Thirteen different experimental combinations given by RSM design were used to investigate the effect of independent process variables on four product responses developed squash. RSM evaluated responses of the 13 squash recipes by second order quadratic equations and found that $\mathrm{pH}$ ranged from 2.69-3.00, ascorbic acid from $102-212 \mathrm{mg} / 100 \mathrm{ml}$, browning from $0.428-0.579$ and overall acceptability scores from $6.25-7.75$. ANOVA analysis showed that the product responses of beverages were significantly affected (at $5 \%$ ) by changes in juice and acidity of the squash recipes. Overall acceptability scores of the beverage increased with the increase in proportion of juice content from 25 to $40 \%$. The coefficient of determination i.e., $\mathrm{R}^{2}$ for all responses was higher than 0.95 and nonsignificant lack of fit was observed for all models; which was desirable. Through numerical optimization, standardized recipe selected by RSM for aonla squash was with $40 \%$ juice and $1 \%$ acidity getting highest desirability of 0.991 . The $\mathrm{pH}$, ascorbic acid, browning and overall acceptability for the optimum recipe predicted by the design were 2.96, $197.8 \mathrm{mg} / 100 \mathrm{ml}, 0.557$ and 7.7, respectively. Thus, present study was first in its kind to optimize aonla squash recipe by using RSM as a tool which gave advantage of not only selecting best recipe but also provided impression of the influence of ingredients used in squash's preparation on its physico-chemical profile.
\end{abstract}

Keywords: Aonla squash, Central composite design, Optimization, Overall acceptability, RSM

\section{INTRODUCTION}

Fruits are amongst the first food items known to be consumed prehistorically by human beings and form a part of the staple diet because these are rich in nutrients and provide some of the essential minerals, vitamins. Apart from this, fruits also help in curing a number of diseases. Aonla or Indian gooseberry (Phyllanthus emblica L.) is one of the traditional fruits indigenous to India and is considered as "Wonder fruit for health" (Ganachari et al., 2010). Aonla, a member of family Euphorbiaceae and sub family Phyllanthiodae, is native to India, Ceylon, Malaya and China (Mishra et al., 2010). India ranks first in the World in area and production of aonla crop (Priya and Khatkar, 2013). Its cultivation is concentrated mainly in Uttar Pradesh, Maharashtra, Gujarat, Rajasthan, Andhra Pradesh, Karnataka and Tamil Nadu (Sahu et al., 2010). Aonla fruit is highly nutritious and known as Kaya Kalp according to Hindu mythology as it restores health and vitality. Aonla is a rare example of an edible material that is rich in tannins as well as ascorbic acid (Pathak et al., 2002). The vitamin C content in aonla varies from 200 to $950 \mathrm{mg} / 100 \mathrm{~g}$ depending upon the variety and size of fruit, which is said to be second highest among all fruits and is next to Barbados Cherry (Ganachari et al., 2010). The main constituents of aonla are tannins, polyphenolic compound 1, 3,6trigalloylglucose, terehebin, corilagin, phyllantnic, linoleic acid, ellagic acid and lupeol. Tannins contain gallic acid and elagic acid, and glucose retards the oxidation of vitamin $\mathrm{C}$ rendering its value as antiscorbutic in the fresh fruit as well as in dried products. Aonla is also a source of carbohydrates, carotene, thiamine, riboflavin, and minerals like iron, calcium and phosphorus. It is valued for its antiscorbutic, diuretic, laxative, antibiotic, acidic, hypoglycaemic, hypolipidemic and cooling properties (Mishra et al., 2010). Aonla, though an underutilized fruit, has enormous potential in the World market. It is almost entirely unknown in the international market and needs to be popularized. Aonla fruits are generally not consumed fresh, as it is highly acidic and astringent (Kumar and Nath, 1993); therefore, it is not popular as a table fruit, but has a great potential in processed forms. Thus, aonla was selected for the present study so that it can be preserved by making juice for its further use in preparation of squash owing to the increasing trend of popu- 
larity among the consumers for fruit based beverages over aerated drinks.

RSM is an attractive tool for carrying out optimization process because it reduced the number of experimental runs required to provide appropriate information for statistically acceptable results (Altan, 2008). Here, central composite design (CCD) was applied. It is composed of a central factorial that forms a cube with sides and has been coded with two units in length (from -1 to +1 ). It was chosen because it was well suited for fitting a quadratic surface, which usually works well for process optimization. Therefore, the present study was planned with the objective to use RSM as a tool for optimizing recipe for aonla squash and to determine the effect of process factors on response parameters.

\section{MATERIALS AND METHODS}

Collection of raw material: Mature aonla fruits cv. Chakaiya was procured from local orchard adjoining Hisar in December, 2014. Sugar was purchased from local market of Hisar, while citric acid was purchased from SRL, laboratories, Mumbai, India.

Collection of aonla juice: Mature aonla fruits were selected for the preparation of squash. The fruits were washed in running water for removal of adhering dirt particles. Juice was processed in large scale multipurpose food processing machine without any heat application for maximum retention of ascorbic acid and other nutrients. Flow sheet for collection of juice from aonla fruits has been presented in Fig. 1. Similar mode of processing has been done by Choudhary et al. (2013) for juice development.

Experimental design layout: Response surface methodology was applied to design the experiment using statistical package of design-expert version 9.01.03 (Stat-Ease Inc., Minneapolis, MN, USA) (Jain, A. and Grewal R.B., 2015). In RSM, central composite design (CCD) was used without blocking with two independent variables and four dependent variables (see Table 1). CCD design was also used for preparation of probiotic beverage using whey and watermelon juice by Khan and Dalakoti ( 2013).The minimum level of each independent variable was selected according to Food safety and standards authority (FSSA) regulations, 2011 and then a range was determined after carrying out preliminary trials. CCD generated 13 experimental runs ( 4 were factorial, 4 were axial and five were at center point). The design gave response surface plots and statistically analyzed experimental data, which helped to understand the effect of juice and acidity per cent on $\mathrm{pH}$, ascorbic acid, browning and overall acceptability of squash and finally optimized the best formulation/recipe for squash development.

Preparation of squash: After analyzing the suitable design for optimization and feeding the different levels of independent factors which were also the ingredients used in squash preparation, the juice and acidity percentages were maintained in 13 experimental recipes according to the runs given by CCD design (Table 2). For preparing squash, total soluble solids and total acids were first analyzed in aonla juice. Total soluble solids were estimated at ambient room temperature by Erma hand refractometer (0-32\%) (FSSAI, 2012). Total acids were extracted in water and were estimated by titration against $0.1 \mathrm{~N}$ sodium hydroxide (Ranganna, 2008). On the basis of this analysis, requisite quantities of sugar and citric acid were dissolved in water by heating and then added to the weighed juice for adjustment of TSS and acidity in the squash (w/w basis). The beverages were strained, mixed with sodium benzoate as per permissible limits given by FSSA, filled in presterilized glass bottles (200 ml capacity) leaving 2.5 $\mathrm{cm}$ headspace and sealed with crown corks. The beverages were stored at ambient room temperature for analysis of responses (Fig. 2).

Determination of product response/physico-chemical parameters: All developed beverages were subjected to analysis for four physico-chemical parameters by different methods. The $\mathrm{pH}$ of squash was determined using Oakton digital pH meter. Ascorbic acid and browning in squash were analyzed by the standard method of AOAC as described in Ranganna, 2008. Sensory evaluation of squash beverages was performed using 9 point hedonic scale described by Ranganna ( 2008). The overall acceptability of the squash was based on the mean scores obtained from all the sensory characters (colour and appearance, flavour, taste, mouthfeel). Sensory evaluation was conducted by five semi-trained judges. The attributes with mean scores of 6 and above out of 9 were considered acceptable. The treatments were replicated thrice.

Statistical analysis for optimization: The statistical analysis were performed by central composite design. The following second-order polynomial (quadratic) model was fitted to dependent variables with the experimental data.

$y=\beta_{0}+{ }^{3} \sum_{i=1} \beta_{i} X_{i}+{ }^{3} \sum_{i=1} \beta_{i i} X_{i i}^{2}+{ }^{3} \sum_{i=1}{ }^{2} \sum_{j=i+1} \beta_{i j} X_{i} X_{j}$

(Eq. 1)

The co-efficients of the polynomial in Eq. 1 were represented by $\beta_{0}$ (constant term), $X_{i}$ (linear effects), $X^{2}{ }_{i i}$ (quadratic effects) and $\mathrm{X}_{\mathrm{i}} \mathrm{X}_{\mathrm{j}}$ (interaction effects). Software generates analysis of variance (ANOVA) tables through which regression coefficients of individual linear, quadratic and interaction terms were determined (Jain et al., 2015). The adequacy of the model was determined using p-value, lack of fit test and coefficient of determination i.e., $\mathrm{R}^{2}$ after model evaluation. The model was generally considered adequate when the calculated F-value was more than significant pvalue (Prob.> F) at 5\% significance level. Model should show high $\mathrm{R}^{2}$ values and non-significant lack of fit for carrying out process of optimization (Saniah and Samsiah, 2012). The 3-D response surfaces and bar 
graphs were produced with the help of statistical package, Design-Expert version-9 from which graphically effect on response variables was determined (Deshpande et al., 2008)

After analyzing all the parameters by second order quadratic models in CCD using RSM Dx-9 software, regression equations were created, studied further for optimization and used for understanding the effect of independent factors on four responses. Results have been discussed one by one taking each response/parameter in consideration which provides a clear outlook how each independent variable/ingredient (juice or acidity \%) influences the quality and acceptance of squash.

\section{RESULTS AND DISCUSSION}

Response parameters of prepared squash: Physicochemical profile of thirteen aonla squash experiments have been summarized in Table 3. Each parameter is considered as individual model for analysis while describing the effects of independent variables on product parameters which were represented as physicochemical parameters of the developed product.

Effect of independent variables on product $\mathbf{p H}$ : $\mathrm{pH}$ is a measure of negative logarithm of hydrogen ion concentration $\left[-\log \left(\mathrm{H}^{+}\right)\right]$. It is an important attribute, which influences the length of storage time of finished/ prepared products. Mean values of $\mathrm{pH}$ ranged from 2.69 to 3.00 of the all the prepared squashes. For understanding the effect of independent variables (juice and acidity \%) on product $\mathrm{pH}$, regression model fitted to experimental result of $\mathrm{pH}$ (see table 3 ) showed the model F-value of 31.46, which implies that the model is adequate and P-value for lack of fit was 0.86

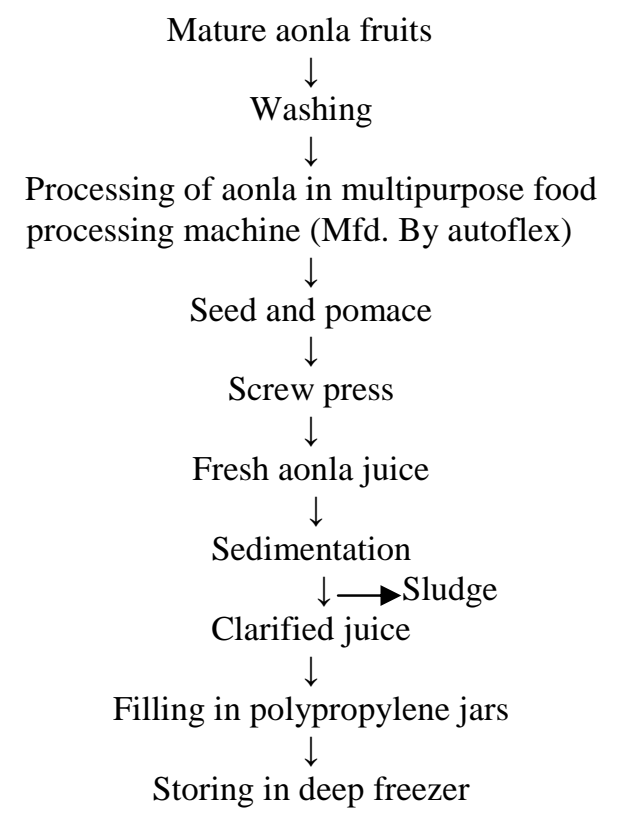

Fig. 1. Flow sheet for collection of juice from aonla fruits.
$(\mathrm{P}>0.05)$, which implies that the lack of fit was nonsignificant i.e., the model was found to be fit and good. The fit of model was also assessed by coefficient of determination i.e., $\mathrm{R}^{2}$, which was found to be 0.96 . Jain et al. (2015) also reported non-significant lack of fit in $\mathrm{pH}$ model with $\mathrm{P}$-value of $0.44(\mathrm{P}>0.05)$ and $0.99 \mathrm{R}^{2}$ value in developed papaya RTS drink. ANOVA analysis (Table 4) indicates that the $\mathrm{pH}$ was significant at $5 \%$ level on linear term of juice (A) and acidity (B) percentage. By neglecting the non-significant terms in Eq. 1 and with the coded values of independent factors, the following equation (Eq. 2) describes the effect of significant process variables on $\mathrm{pH}$ of the prepared beverages: $\mathrm{pH}=+9.6-0.01 * \mathrm{~A}-10.53 * \mathrm{~B}\left(\mathrm{R}^{2}=0.96\right)($ Eq. 2$)$

In Eq. 2 (demonstrating $\mathrm{pH}$ interpretation), negative coefficients of linear terms depict that $\mathrm{pH}$ decreased with the increase in quantity of juice and acids. Not a single interaction and quadratic term had any effect on the $\mathrm{pH}$ of the squash beverage. Saniah and Hasimah (2008) developed Morinda citrifolia citrus-flavoured (calamansi) drink using RSM and found that percentage of citrus juice significantly affected (at 5\% level) the $\mathrm{pH}$ value of Morinda drink compared to Morinda juice. The variations in $\mathrm{pH}$ with process variables are graphically presented in the 3-D surface plots (Fig. 3).

Effect of independent variables on Ascorbic acid: Ascorbic acid acts as an antioxidant and prevents the oxidative deterioration of other important nutrients in the product. In thirteen experimental recipes generated by RSM, it ranged from 102 to $212 \mathrm{mg} / 100 \mathrm{ml}$ (see table 3). For understanding the effect of independent variables (juice and acidity \%) on product ascorbic acid content, regression model fitted to experimental result of ascorbic acid (see table 3 ) showed the model had F-value of 2043.75, which implies that the model

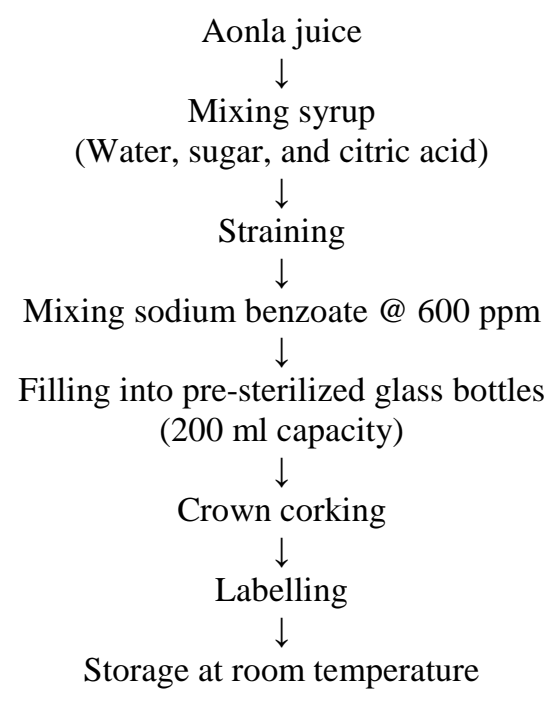

Fig. 2. Flow sheet for preparation of aonla squash. 


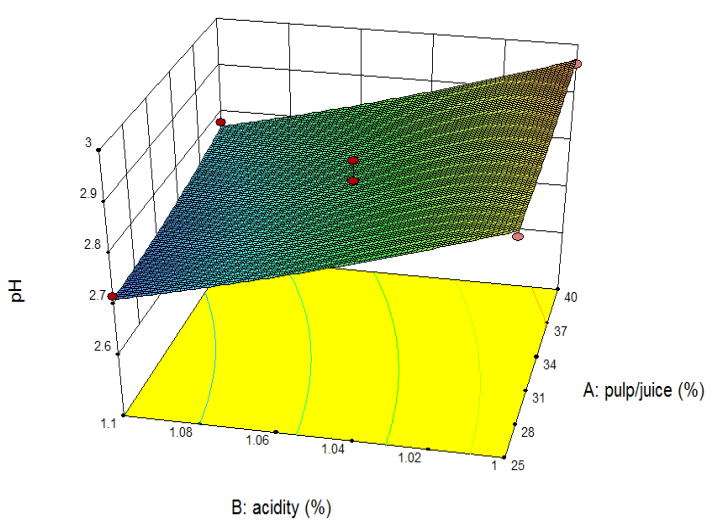

Fig. 3. Effect of process variables on $\mathrm{pH}$.

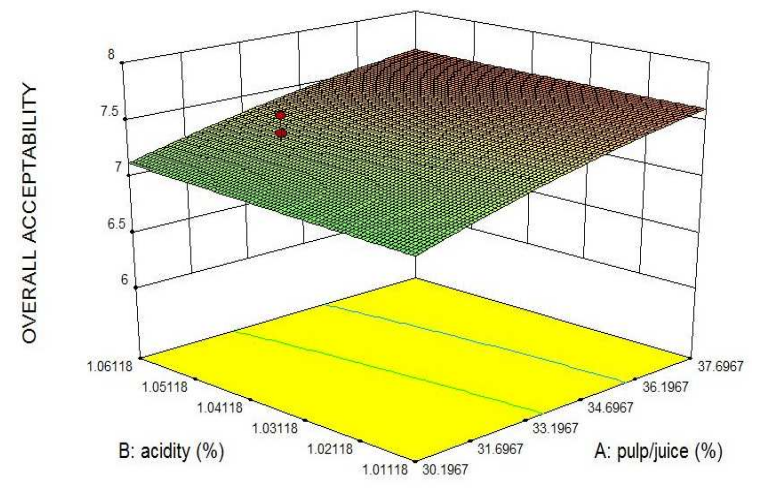

Fig. 5. Effect of process variables on overall acceptability scores.

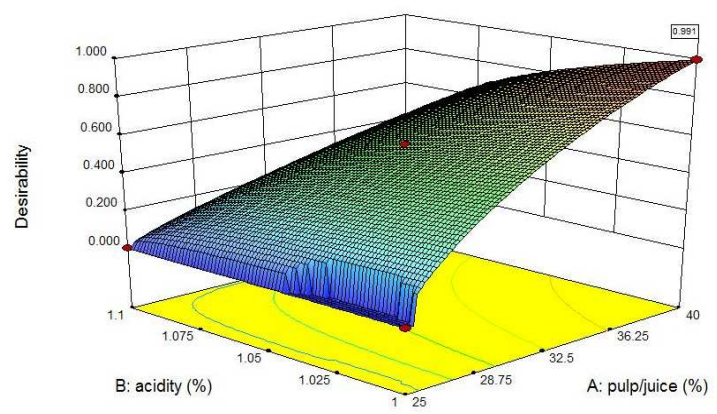

Fig. 7a. 3-D graph showing desirability (0.991) of optimum recipe.

is significant and P-value for lack of fit was 0.17 $(\mathrm{P}>0.05)$, which implies that the lack of fit was nonsignificant. Coefficient of determination i.e., $\mathrm{R}^{2}$ was also very high (0.99) but when Devaki and Premavalli (2012), developed fermented ashgourd beverage, they reported lower $\mathrm{R}^{2}$ value of 0.93 and lower Vitamin-C content from 0.02 to $0.21 \mathrm{mg} / 100 \mathrm{~g}$ as compared to aonla squash which was due to lower content of ascorbic acid present in ashgourd as compared to aonla fruit whereas Jaiswal et al. (2008) prepared aonla squash using $45 \%$ pulp, $50 \%$ TSS and $1 \%$ acidity and reported

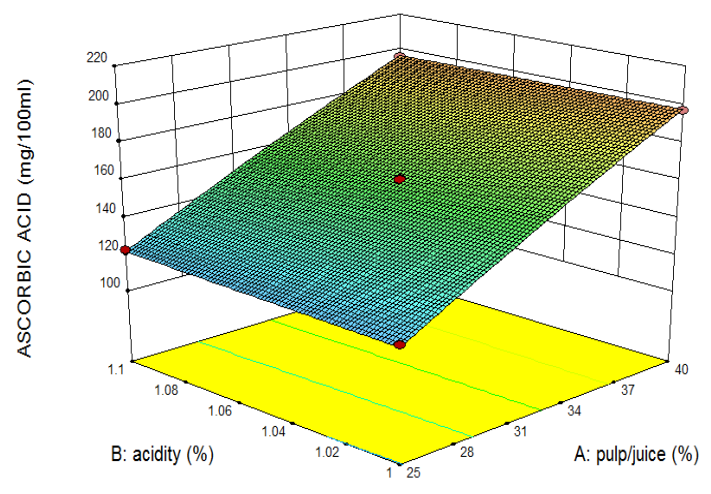

Fig. 4. Effect of process variables on ascorbic acid.

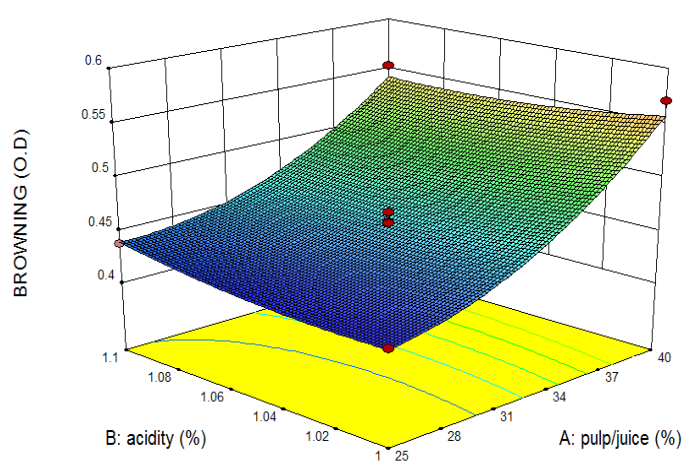

Fig. 6. Effect of process variables on browning.

$$
\text { Desirability }
$$

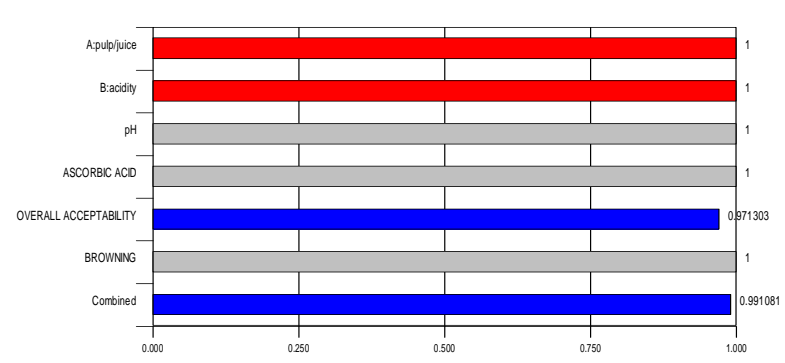

Fig. 7b. Bar graph showing desirability of each response parameters for optimization.

Table 1. Factors for response surface study and their levels.

\begin{tabular}{lcccccc}
\hline Process & Co & \multicolumn{5}{c}{ Variables level codes } \\
\cline { 3 - 7 } variable & de & -1.414 & -1 & 0 & 1 & 1.414 \\
\hline Juice (\%) & $\mathrm{A}$ & 21.9 & 25 & 32.5 & 50 & 43.1 \\
Acidity (\%) & $\mathrm{B}$ & 0.97 & 1 & 1.05 & 1.1 & 1.12 \\
\hline
\end{tabular}

$78.30 \mathrm{mg} / 100 \mathrm{ml}$ ascorbic acid content. ANOVA analysis (see Table 4) indicates that the ascorbic acid was highly significant at $5 \%$ level on linear term of juice (A) and quadratic term of $\left(\mathrm{A}^{2}\right)$. By neglecting the non-significant terms in Eq. 1 and with the coded values of independent factors, the following equation (Eq. 
Akanksha Jain et al. / J. Appl. \& Nat. Sci. 8 (3): 1341 - 1348 (2016)

Table 2. Response surface experimental design in terms of coded levels and actual levels.

\begin{tabular}{|c|c|c|c|c|c|}
\hline \multirow[t]{3}{*}{ Run } & \multirow[t]{3}{*}{ Space type } & \multicolumn{2}{|c|}{ Coded values } & \multicolumn{2}{|c|}{ Actual values } \\
\hline & & $\mathbf{X}_{1}$ & $\mathbf{X}_{2}$ & & \\
\hline & & $\mathbf{A}$ & B & Juice (\%) & Acidity (\%) \\
\hline 1. & Factorial & 1.000 & -1.000 & 40.0 & 1.00 \\
\hline 2. & Axial & 0.000 & 1.414 & 32.5 & 1.12 \\
\hline 3. & Axial & 1.414 & 0.000 & 43.1 & 1.05 \\
\hline 4. & Center & 0.000 & 0.000 & 32.5 & 1.05 \\
\hline 5. & Factorial & -1.000 & -1.000 & 25.0 & 1.00 \\
\hline 6. & Center & 0.000 & 0.000 & 32.5 & 1.05 \\
\hline 7. & Factorial & -1.000 & 1.000 & 25.0 & 1.10 \\
\hline 8. & Axial & -1.414 & 0.000 & 21.9 & 1.05 \\
\hline 9. & Center & 0.000 & 0.000 & 32.5 & 1.05 \\
\hline 10. & Axial & 0.000 & -1.414 & 32.5 & 0.97 \\
\hline 11. & Center & 0.000 & 0.000 & 32.5 & 1.05 \\
\hline 12. & Center & 0.000 & 0.000 & 32.5 & 1.05 \\
\hline 13. & Factorial & 1.000 & 1.000 & 40.0 & 1.10 \\
\hline
\end{tabular}

Table 3. 13 Experimental recipes with response parameters of aonla squash.

\begin{tabular}{|c|c|c|c|c|c|c|}
\hline \multirow[b]{2}{*}{ Run No. } & \multicolumn{2}{|c|}{$\begin{array}{c}\text { Independent factors } \\
\text { (Major ingredients of } \\
\text { squash) }\end{array}$} & \multicolumn{4}{|c|}{$\begin{array}{c}\text { Dependent/ response factors } \\
\text { (Physico-chemical profile of prepared squash) }\end{array}$} \\
\hline & Juice (\%) & $\begin{array}{c}\text { Acidity } \\
(\%)\end{array}$ & $\mathbf{p H}$ & $\begin{array}{c}\text { Ascorbic acid } \\
(\mathrm{mg} / \mathbf{1 0 0} \mathrm{ml})\end{array}$ & $\begin{array}{l}\text { Overall acceptabil- } \\
\text { ity scores (out of 9) }\end{array}$ & $\begin{array}{c}\text { Browning } \\
(\mathbf{O . D} @ 440 \mathrm{~nm})\end{array}$ \\
\hline 1. & 40.0 & 1.00 & 2.96 & 197.4 & 7.75 & 0.571 \\
\hline 2. & 32.5 & 1.12 & 2.69 & 161.1 & 7.60 & 0.467 \\
\hline 3. & 43.1 & 1.05 & 2.88 & 212.0 & 7.70 & 0.579 \\
\hline 4. & 32.5 & 1.05 & 2.82 & 161.5 & 7.50 & 0.442 \\
\hline 5. & 25.0 & 1.00 & 2.91 & 120.5 & 6.25 & 0.422 \\
\hline 6. & 32.5 & 1.05 & 2.83 & 160.2 & 7.35 & 0.455 \\
\hline 7. & 25.0 & 1.10 & 2.72 & 122.8 & 6.50 & 0.438 \\
\hline 8. & 21.9 & 1.05 & 2.81 & 101.8 & 6.25 & 0.428 \\
\hline 9. & 32.5 & 1.05 & 2.8 & 161.0 & 7.30 & 0.458 \\
\hline 10. & 32.5 & 0.97 & 3.0 & 159.8 & 7.25 & 0.461 \\
\hline 11. & 32.5 & 1.05 & 2.87 & 159.4 & 7.30 & 0.459 \\
\hline 12. & 32.5 & 1.05 & 2.8 & 160.7 & 7.10 & 0.468 \\
\hline 13. & 40.0 & 1.10 & 2.78 & 195.5 & 7.70 & 0.553 \\
\hline
\end{tabular}

Table 4. Regression coefficients and ANOVA of the second-order polynomial quadratic models.

\begin{tabular}{|c|c|c|c|c|c|c|c|c|}
\hline \multirow{3}{*}{$\begin{array}{l}\text { Parameters } \\
\text { Coefficient }\end{array}$} & \multicolumn{8}{|c|}{ Estimated $p$ and $F$ value of different models } \\
\hline & \multicolumn{2}{|c|}{ pH } & \multicolumn{2}{|c|}{ Ascorbic acid } & \multicolumn{2}{|c|}{$\begin{array}{c}\text { Overall } \\
\text { acceptability }\end{array}$} & \multicolumn{2}{|c|}{ Browning } \\
\hline & $\begin{array}{c}\text { p- } \\
\text { value }\end{array}$ & F value & $\begin{array}{c}\text { p- } \\
\text { value }\end{array}$ & F value & $\begin{array}{c}\text { p- } \\
\text { value }\end{array}$ & F value & $\begin{array}{c}p- \\
\text { value }\end{array}$ & F value \\
\hline Intercept $\left(\beta_{0}\right)$ & 0.0001 & 31.46 & $<0.0001$ & 2043.75 & 0.0003 & 23.59 & $<0.0001$ & 48.04 \\
\hline A-Juice $\left(\beta_{1}\right)$ & $0.0169 *$ & 9.72 & $<0.0001 *$ & 10195.65 & $<0.0001 *$ & 103.61 & $<0.0001 *$ & 202.53 \\
\hline$B$-Acidity $\left(\beta_{2}\right)$ & $<0.0001 *$ & 145.41 & 0.4562 & 0.62 & 0.1801 & 2.22 & 0.8522 & 0.037 \\
\hline $\mathrm{AB}\left(\beta_{12}\right)$ & 0.8389 & 0.045 & 0.0930 & 3.78 & 0.3935 & 0.83 & 0.1950 & 2.05 \\
\hline $\mathrm{A}^{2}\left(\beta_{11}\right)$ & 0.3082 & 1.21 & $0.0037 *$ & 18.26 & $0.0135 *$ & 10.74 & $0.0006^{*}$ & 35.00 \\
\hline $\mathrm{B}^{2}\left(\beta_{22}\right)$ & 0.3082 & 1.21 & 0.9259 & $9.301 E-003$ & 0.7585 & 0.10 & 0.1709 & 2.33 \\
\hline Lack of Fit** & 0.86 & 0.25 & 0.17 & 2.87 & 0.29 & 1.77 & 0.21 & 2.39 \\
\hline $\mathrm{R}^{2}$ & \multicolumn{2}{|c|}{0.96} & \multicolumn{2}{|c|}{0.99} & \multicolumn{2}{|c|}{0.94} & \multicolumn{2}{|c|}{0.97} \\
\hline Predicted- $\mathrm{R}^{2}$ & \multicolumn{2}{|c|}{0.89} & \multicolumn{2}{|c|}{0.996} & \multicolumn{2}{|c|}{0.74} & \multicolumn{2}{|c|}{0.95} \\
\hline Adjusted- $\mathrm{R}^{2}$ & \multicolumn{2}{|c|}{0.92} & \multicolumn{2}{|c|}{0.998} & \multicolumn{2}{|c|}{0.90} & \multicolumn{2}{|c|}{0.85} \\
\hline
\end{tabular}

3) describes the effect of significant process variables on ascorbic acid of the squash beverages:

Ascorbic acid $=+160.59+38.20 * \mathrm{~A}-1.73 * \mathrm{~A}^{2}\left(\mathrm{R}^{2}=0.99\right)$

(Eq. 3)

In Eq. 3 (demonstrating ascorbic acid interpretation), positive and negative coefficients of linear and quad- 
Akanksha Jain et al. / J. Appl. \& Nat. Sci. 8 (3): 1341 - 1348 (2016)

Table 5. Criteria established for different factors in numerical optimization process.

\begin{tabular}{lcccc}
\hline \multicolumn{1}{c}{ Factors } & Goal & $\begin{array}{c}\text { Lower } \\
\text { Limit }\end{array}$ & $\begin{array}{c}\text { Upper } \\
\text { Limit }\end{array}$ & Importance \\
\hline A:Juice & maximize & 25 & 40 & 5 \\
B:Acidity & minimize & 1 & 1.1 & 4 \\
pH & in range & 2.69 & 3 & 3 \\
Ascorbic acid & in range & 101.8 & 212.07 & 4 \\
Overall acceptability & maximize & 6.25 & 7.75 & 4 \\
Browning & in range & 0.422 & 0.579 & 4 \\
\hline
\end{tabular}

Table 6: Five solutions generated by Response surface statistical package.

\begin{tabular}{cccccccc}
\hline $\begin{array}{l}\text { Run } \\
\text { No. }\end{array}$ & Juice (\%) & $\begin{array}{c}\text { Acidity } \\
(\%)\end{array}$ & pH & $\begin{array}{c}\text { Ascorbic acid } \\
(\mathbf{m g} / \mathbf{1 0 0} \mathbf{~ m l})\end{array}$ & O.A. scores* & Browning & Desirability \\
\hline 1 & 40 & 1.0 & 2.96 & 197.8 & 7.70 & 0.557 & 0.991 \\
2 & 39.5 & 1.0 & 2.96 & 195.4 & 7.68 & 0.549 & 0.974 \\
3 & 40 & 1.01 & 2.94 & 197.6 & 7.70 & 0.553 & 0.954 \\
4 & 40 & 1.02 & 2.93 & 197.5 & 7.70 & 0.551 & 0.936 \\
5 & 40 & 1.02 & 2.92 & 197.5 & 7.70 & 0.551 & 0.934 \\
\hline
\end{tabular}

*O.A. = Overall acceptability sensory scores (out of 9), Run No. 1- selected for optimization

Run. No.1 is selected as optimized recipe

ratic terms depict that ascorbic acid content increased with the increase in quantity of juice $(A)$ and decreased with the quadratic variable $\left(\mathrm{A}^{2}\right)$. Similar results were recorded by Devaki and Premavalli (2012), who developed bittergourd fermented beverage using RSM and reported that fermentation time (A) and curd concentration (B), which are the process variables in the experiment had significant positive effect (at 5\% level) on vitamin $\mathrm{C}$ content at linear level. The variations in ascorbic acid with process variables were graphically presented in the 3-D surface plots (Fig. 4).

Effect of independent variables on overall acceptability: Sensory evaluation is important because it indicates the overall acceptability of a product. Overall acceptability scores of the experimental recipes ranged from 6.25 to 7.75. For understanding the effect of independent variables (juice and acidity \%) on product overall acceptability scores, regression model fitted to experimental result of overall acceptability scores (see table 3) showed the model had F-value of 23.59, which implies that the model is adequate and P-value for lack of fit was 0.29 ( $\mathrm{P}>0.05)$, which implies that the lack of fit was non-significant. Coefficient of determination i.e., $\mathrm{R}^{2}$ was also high (0.94). ANOVA analysis (Table 4) indicates that the overall acceptability of aonla squash was highly significant at $5 \%$ level on linear term of juice (A) and quadratic term of $\left(\mathrm{A}^{2}\right)$. Previous investigation by Melo et al. (2013) optimized peach nectar (low calorie) via. RSM and found that F-test value and $\mathrm{R}^{2}$ for overall liking was 101.2 and 0.99 , respectively while Majumdar et al. (2012) reported 51.90 F-value and $0.97 \mathrm{R}^{2}$ value for sensory scores in developed ashgourd-mint leaves juice using RSM. By neglecting the non-significant terms in Eq. 1 and with the coded values of independent factors, the following equation (Eq. 4) describes the significant effect of process variables on overall acceptability of the squash beverages:

Overall acceptability $=+7.31+0.59 * \mathrm{~A}-0.21 * \mathrm{~A}^{2}\left(\mathrm{R}^{2}=\right.$ $0.94)$ (Eq. 4)

In Eq. 4 (demonstrating overall acceptability interpretation), positive and negative coefficients of linear and quadratic terms depict that overall acceptability scores of aonla squash increased with the increase in quantity of juice and decreased with the quadratic variable $\left(\mathrm{A}^{2}\right)$. Similarly, Kumar and Singh (2012) developed mango based whey beverage in which effect of quantity of mango pulp, stabilizer and sucrose were studied on overall acceptability of beverage using response surface methodology (RSM). They reported that increase in mango pulp (A) and sucrose (C) caused significant effect (at 5\% level) on overall acceptability scores of the beverage and more increase was found with mango pulp than sucrose.

The variations in overall acceptability scores with process variables are graphically presented in the 3-D surface plots (Fig. 5).

Effect of independent variables on browning: Nonenzymatic browning (NEB) reactions generally lead to colour change either due to ascorbic acid decomposition or oxidation in ascorbic acid rich beverages. OD ranged from 0.422 to 0.579 . NEB of aonla juice was found to be $0.035 \mathrm{OD}$ at the time of juice preparation to very high OD of 0.822 after 8 months room temperature storage as reported by Bhattachaterjee et al. (2012). For understanding the effect of independent variables (juice and acidity \%) on product overall acceptability scores, regression model fitted to experimental result of browning (see table 3) showed the model had F-value of 48.04, which implies that the model is significant and Pvalue for lack of fit was $0.21(\mathrm{P}>0.05)$, which implies that the lack of fit was non-significant (see table 4). Coefficient of determination i.e., $\mathrm{R}^{2}$ was also high (0.97). 
ANOVA analysis (Table 4) indicates that the browning of aonla squash was significant at $5 \%$ level on linear term of juice $(\mathrm{A})$ and quadratic term of $\left(\mathrm{A}^{2}\right)$. By neglecting the non-significant terms in Eq. 1 and with the coded values of independent factors, the following equation (Eq. 5) describes the significant effect (at 5\% level) of process variables i.e are juice and acidity on browning of the prepared beverages:

Browning $=+0.46+0.06 * \mathrm{~A}+0.027 * \mathrm{~A}^{2}\left(\mathrm{R}^{2}=0.97\right)($ Eq. 5) In Eq. 5 (demonstrating browning interpretation), positive coefficients of linear and quadratic terms depicts that browning of aonla squash increased with increase in quantity of juice variable (A) and quadratic variable of juice $\left(\mathrm{A}^{2}\right)$. Acidity percentages have been found no effect on browning of prepared aonla squash. The variations in browning with process variables are graphically presented in the 3-D surface plots (Fig. 6).

Optimum conditions for standardization of recipe for aonla squash using RSM: Dx-9 RSM software could adequately be used to standardize the process under the desired operating conditions as observed from the ANOVA results of the second order polynomial response models in Table 4 and regression equations (Eq. 2 to 5 ).

RSM gives the best recipe from different recipes (13 in number) after establishing certain criteria or conditions for each factor for preparation of good quality and acceptable beverage. Deshpande et al. (2008) also successfully optimized chocolate flavoured peanut-soy beverage using RSM as applied to only consumer acceptability data using 9-point hedonic scale from 28 beverage formulations whereas our study employed four product responses to judge the beverage quality and optimization process. For optimization process, preferred criterion for each independent factor and response parameters was set from the numerical optimization menu displayed at the left hand side of the CCD design. Criteria can be set manually, else program will consider automatically. But, preferably conditions should be set manually with certain objectives keeping in mind maximum nutrition, acceptability of consumer and different taste preferences of the major population. In the present study, goal of experiment for selection of best recipe was to obtain aonla squash with maximum juice content and overall acceptability scores and minimum acidity, while $\mathrm{pH}$, ascorbic acid and browning values were kept in the range (Table 5).

All the above given criteria were combined and program generated five solutions with the help of 'solutions' option on the left hand side of the CCD design but amongst them run no. 1 from table 6 was selected with $40 \%$ juice and $1.0 \%$ acidity showing highest desirability and appeal. Thus, aonla squash recipe prepared with $40 \%$ juice, $1.0 \%$ acidity and adjusting 50\% TSS was selected for standardization with highest desirability of 0.991 (Fig. 7a and 7b). The optimum solution no. 1 with maximum desirability of
0.991 (should approach to unity) from table no. 6 indicated that the selected aonla squash beverage recipe cv. chakaiya when prepared with $40 \%$ juice, $50 \%$ TSS and $1 \%$ acidity, it gave predicted value of $2.96 \mathrm{pH}$, $197.8 \mathrm{mg} / 100 \mathrm{ml}$ ascorbic acid content, 0.557 browning and 7.7 overall acceptability score.

Rebouças et al. (2014) also optimized prebiotic beverage from broken cashew nut kernels hydrosoluble extract and passion fruit juice with the addition of $3 \%$ sugar using Response surface methodology (CCD) in order to optimize acceptance of its sensory attributes. Formulation with $14 \%$ oligofructose (A) and $33 \%$ passion fruit juice (B) were optimized using RSM from 9 experimental recipes. Likewise; present study employs two independent factors such as juice \% (A) and acidity $\%$ (B) for preparation of aonla squash with the application of CCD design which gives 13 formulation/ recipes contrary to 9 formulations prepared by Rebouças et al. (2014). This difference could be due to number of varied response or dependent parameters taken for study. Our study optimized not only the overall acceptability of the aonla squash (indicator of sensory acceptance) but also the chemical profile too which is essential to predict quality of the aonla squash. Formulation with $40 \%$ juice, $1 \%$ acidity, with the addition of $50 \%$ sugar were found best amongst 13 formulations.

\section{Conclusion}

It can be concluded from the present investigation that central composite design and response surface methodology can be successfully applied for optimizing aonla squash recipe. The different levels of ingredients such as percentages of juice ( 25 to $40 \%$ ) and acidity (1.0 to $1.10 \%$ ) employed for the preparation of aonla squash showed that these two variables markedly affected $\mathrm{pH}$, ascorbic acid content, browning and overall acceptability scores of the prepared beverage. These can be related to the ingredients levels by using second order polynomials which showed that model $\mathrm{p}$-values for all response/ physico-chemical variables were less than 0.05 which make it significant at 5\% level. Results showed that higher percentage of aonla juice (upto $40 \%$ ) in squash resulted in increased ascorbic acid content, browning and higher overall acceptability scores of prepared beverages. Study showed that sensory panelists generally responded with a high level of acceptance for squash formulations containing $40 \%$ juice and $1.0 \%$ acidity with highest scores of 7.75 (out of 9). For selection of best recipe/formulation amongst thirteen recipes, recipe with $40 \%$ juice and $1.0 \%$ acidity with highest appeal or desirability of 0.991 was chosen by attractive statistical package i.e RSM with the help of numerical optimization option. Thus, present study was former to use response surface methodology as a tool for optimizing aonla squash recipe of variety chakaiya, which gave advantage of not only 
selecting best formulation from different recipes but also gave imprint of the effect of ingredients used in preparation (juice and acidity contents) on squash's physico-chemical profile with the help of regression equations and 3D-surface plots. This information would further help in developing newer and qualitative beverages.

\section{ACKNOWLEDGEMENTS}

The present work was investigated under the guidance of elite members of advisory committee; Dr. Rakesh Gehlot, Dr. Saleem Siddiqui, Dr. S.K. Sehrawat and Dr. Manju Tonk, Faculty Members at CCS, Haryana Agricultural University (HAU), Hisar, Haryana-125 004 for their inexhaustible encouragement and sincere co-operation and HAU for providing facilities.

\section{REFERENCES}

Altan, A., McCarthy, K.L. and Maskan, M. (2008). Evaluation of snack foods from barley-tomato pomace blends by extrusion processing. J. Food Engg. 84: 231-242.

Bhattachaterjee, A.R., Tandon, D.K., Kumar, S. and Dikshit, A. (2012). Quality of aonla juice as affected by storage temperature. Bev. Food World. 39(4): 54-56.

Choudhary, M. L., Verma, I. M., Jitendra, S., Atul, C. and Godara, S. L. (2013). Studies on biochemical changes in aonla (Emblica officinalis Gaertn.) squash under storage condition. Progressive Hortic. 45(2): 281-285.

Deshpande, R.P., Chinnan, M.S. and McWatters, K.H (2008). Optimization of a chocolate-flavored, peanutsoy beverage using response surface methodology (RSM) as applied to consumer acceptability data. $L W T$ Food Sci. Technol. 41(8):1485-1492.

Devaki, C.S. and Premavalli, K.S. (2012). Development of bitter gourd fermented beverage using response surface methodology. J. Pharmacy Nutri. Sci. 2: 94-103.

Devaki, C.S. and Premavalli, K.S. (2012). Development of Fermented Beverage Using RSM and Nutrients Evaluation. J. Food Res. 1(3):138-147.

Ganachari, A., Thangavel, K., Mazara Ali, S., Nidoni, U. and Ananthacharya. (2010) Physical properties of Aonla fruit relevant to the design of processing equipments. Int. J. Engg. Sci. Technol. 2(12): 7562-7566.

Jain, A. and Grewal, R.B. (2015). Development and quality evaluation of value added extruded snacks by supplementing amaranth and guar gum in mixed cereal flour formulation constituting maize, rice and wheat. Int. J. Recent Sci. Res. 6(9): 6221-6227.

Jain, A., Gahlot, R. and Sidiqqui, S. (2015). Optimization of recipe for preparation of papaya ready-to-serve drink using response surface methodology (RSM). J. Agric. Engg. Food Technol. 2(3): 155-161.

Jaiswal, R., Singh, G. and Singh, A.K. (2008). Evaluation of aonla cultivars for squash making. Prog. Agric. 8(1):29-31.

Khan, H. and Dalakoti, H. (2013). Probiotication of beverages using whey and watermelon juice. Food Sci. Res. J. 23: 576-579.

Kumar, A. and Singh, K. (2012). Utilization of whey for the production of instant energy beverage by using response surface methodology. Adv. J. Food Sci. Technol. 4 (2):103-111.

Kumar, S. and Nath, V. (1993). Storage stability of aonla fruits: a comparative study of zero energy cool chamber versus room temperature. J. Food Sci. Technol. 30(3): 202-203.

Majumdar, T.K., Wadikar, D.D. and Bawa, A.S. (2012). Development and storage stability of aseptically processed ash gourd-mint leaves juice. Int. Food Res. J. 19 (3):823-828.

Manual for analysis of fruits and vegetable products. (2012). 'Determination of total soluble solids', pp.4-5. Retrieved from www.fssai.gov.in/ draft manuals/fruits \& vegetable.pdf

Melo, L., Cardoso, J.M.P., Battochio, J.R. and Bolini, H.M.A. (2013). Using response surface methodology and highintensity sweeteners positive synergy to optimize peach nectar acceptability. Food Nutr. Sci. 4:503-509.

Mishra, V., Mishra, P. and. Rai, G.K. (2010). Process and product standardization for the development of amla bar. Beverage \& Food World. 34(6): 58-60.

Pathak, R.K., Pandey, D., Hasseb, M., Tandon, D.K. and Mishra, A.K. 2002. Aonla. CISH, Lucknow, p. 36.

Priya, M.D. and Khatkar, B.S. (2013). Effect of processing methods on keeping quality of aonla (Emblica officinalis Gaertn.) preserve. Int. Food Res. J. 20(2): 617-622.

Ranganna, S. (2008). Handbook of Analysis and Quality Control for Fruit and Vegetable Products. $2^{\text {nd }}$ Ed. Tata McGraw Hills Publishing Co. Ltd., New Delhi.

Rebouças, M.C., Rodrigues, M.C. and Afonso, M.R. (2014). Optimization of the acceptance of prebiotic beverage made from cashew nut kernels and passion fruit juice. $J$. Food Sci. 79(7): 1750-1755.

Sahu, G.D., Singh, P. and Singh, A.K. (2010). Studies on the physico-chemical changes in Aonla preserve (Murabba) of three cultivars during storage. Res. J. Agric. Sci. 1(4): 419-425.

Saniah, K. and Hasimah, H.A. (2008). Development of Morinda citrifolia citrus-flavoured drink using Response Surface Methodology (RSM). J. Trop. Agric. 36 (1): 87-89. 